\title{
The Phillips curve, the persistence of inflation, and the Lucas critique: evidence from exchange-rate regimes: comment
}

Citation for published version (APA):

Kool, C. J. M., \& Lammertsma, A. (1997). The Phillips curve, the persistence of inflation, and the Lucas critique: evidence from exchange-rate regimes: comment. METEOR, Maastricht University School of Business and Economics. METEOR Research Memorandum No. 041 https://doi.org/10.26481/umamet.1997041

Document status and date:

Published: 01/01/1997

DOI:

10.26481/umamet.1997041

Document Version:

Publisher's PDF, also known as Version of record

Please check the document version of this publication:

- A submitted manuscript is the version of the article upon submission and before peer-review. There can be important differences between the submitted version and the official published version of record.

People interested in the research are advised to contact the author for the final version of the publication, or visit the DOI to the publisher's website.

- The final author version and the galley proof are versions of the publication after peer review.

- The final published version features the final layout of the paper including the volume, issue and page numbers.

Link to publication

\footnotetext{
General rights rights.

- You may freely distribute the URL identifying the publication in the public portal. please follow below link for the End User Agreement:

www.umlib.nl/taverne-license

Take down policy

If you believe that this document breaches copyright please contact us at:

repository@maastrichtuniversity.nl

providing details and we will investigate your claim.
}

Copyright and moral rights for the publications made accessible in the public portal are retained by the authors and/or other copyright owners and it is a condition of accessing publications that users recognise and abide by the legal requirements associated with these

- Users may download and print one copy of any publication from the public portal for the purpose of private study or research.

- You may not further distribute the material or use it for any profit-making activity or commercial gain

If the publication is distributed under the terms of Article $25 \mathrm{fa}$ of the Dutch Copyright Act, indicated by the "Taverne" license above, 
The Phillips Curve, the Persistence of Inflation, and the Lucas Critique:

Evidence from Exchange-Rate Regimes: Comment

by Clemens J.M. Kool and Alex Lammertsma ${ }^{1}$

November 1997

\footnotetext{
${ }^{1}$ LIFE and Department of Economics, University Maastricht, Maastricht, the Netherlands. We thank Roel Beetsma, Kees Koedijk, Joan Muysken, and Tom van Veen for useful discussions and comments. Any remaining errors are our own.
} 


\section{The Phillips Curve, the Persistence of Inflation, and the Lucas Critique: Evidence from Exchange-Rate Regimes: Comment}

In a recent paper in this Review, Alogoskoufis and Smith (1991) - henceforth AS - make an important contribution with respect to the theory on the effectiveness of systematic monetary policy under different exchange rate regimes. In particular, they use a symmetric two-country macro-model with forward-looking price-setters, to show first that higher monetary accommodation increases the persistence of average inflation across countries, and second that higher exchange rate accommodation increases the persistence of inflation differentials between countries.

The purpose of this comment is to demonstrate that their theoretical result concerning the first order derivative of relative inflation persistence with respect to the degree of accommodation is incorrect. ${ }^{2}$ As a consequence, the sign of the first derivative becomes ambiguous. We provide an economic explanation of this result, elaborating on the three distinct transmission mechanisms in the AS (relative) model. Moreover, we propose an economically meaningful modification of the original AS model that restores a strictly positive relation between exchange rate accommodation and relative inflation persistence.

\footnotetext{
${ }^{2}$ Alogoskoufis (1992) uses a related model under alternative assumptions about price- and wage-setting to come up with the same conclusion about the positive link between exchange rate accommodation and relative inflation persistence as do AS. That result is flawed too.
} 
AS use a simple aggregate demand-supply model for their analysis. ${ }^{3}$ On the demand side, a standard demand for money function (LM-curve) is used in combination with IS-equilibrium conditions, where aggregate demand depends on the real interest rate and the real exchange rate. Also uncovered interest parity is assumed. On the supply side, each economy consists of a large number of monopolistically competitive firms, output is proportional to employment, and firms face a downward sloping demand curve. Due to price adjustment costs, prices follow a secondorder differential equation. Wage setting is forward-looking and depends on expected future prices and labor market conditions. The monetary regime is characterized by two rules:

Install Equation Editor and double-

click here to view equation.

Install Equation Editor and double-

click here to view equation.

where $\psi$ is the degree of monetary accommodation and $\phi$ the degree of exchange rate accommodation. In these equations, $p$ is the logarithm of the price level, and $m$ of the money supply. The logarithmic exchange rate in number of units of home currency per unit of foreign Install Equation Editor and double-

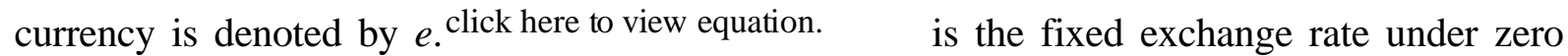
accommodation. $\mu$ denotes an exogenous stochastic component. Asterikses refer to the foreign country.

\footnotetext{
${ }^{3}$ For an exact description of the model, we refer to AS. A detailed analysis is contained in Lammertsma (1997).
} 
AS demonstrate that the model can be solved by decomposing it into two independent second-order systems for the price level: an average (world) model, where the two countries are summed and divided by 2 , and a relative model where the difference between the two countries is considered. Equation (1) is relevant for the average model and reflects the development of the world money supply, as a function of the world price level and $\mu$, while equation (2) focuses on the difference or asymmetry between the two countries by modeling the exchange rate as a function of the price differential. In this comment we exclusively concentrate on the relative model, since it is seriously flawed and correct derivations lead to significant changes in results and interpretation. $^{4}$

\section{The relative model}

Variables with a "hat" denote differences between the home and foreign country. The following second order difference equation for (expected) relative price levels can be derived from the relative model:

Install Equation Editor and double-

click here to view equation.

Install Equation Editor and doubleclick here to view equation.

where

Install Equation Editor and doubleclick here to view equation.

\footnotetext{
${ }^{4}$ The AS results for the average model contain some errors too. These remain unreported as the final conclusions with respect to the sensitivity of world inflation persistence to the degree of monetary accommodation remain unaltered. The correct results are available from the authors on request, however.
} 
In equations (3) and (4), $\lambda$ is the firm's intertemporal discount factor, while $\theta$ measures the firm's marginal adjustment cost of prices relative to the cost of deviating from the optimal steady-state price. $\alpha$ and $\beta$ measure the responsiveness of output demand to the real interest rate and the real exchange rate respectively. $\delta$ is the share of domestic goods in consumption and $\varepsilon$ is the Install Equation Editor and double-

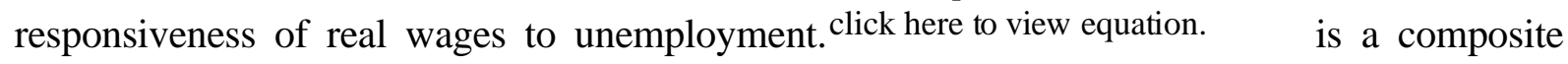
Install Equation Editor and doubleexogenous variable that depends on the relative reservation wage (click here to view equation. ）, Install Equation Editor and doublerelative labor supply (click here to view equation. ), relative labor productivity Install Equation Editor and doubleInstall Equation Editor and double(click here to view equation. ), a relative demand shock (click here to view equation. ), and Install Equation Editor and doublefirms' relative benchmark inflation rate (click here to view equation. ${ }^{5}$

For further analysis, note that (3) is a second order difference equation that may be rewritten as:

Install Equation Editor and doubleclick here to view equation.

where $\zeta_{1}$ and $\zeta_{2}$ are real positive roots on either side of unity under the (sufficient) assumption that $\phi<1$. Then, relative (expected) inflation can be shown to follow an $\operatorname{AR}(1)$ process with autoregressive parameter $\zeta_{1}(<1)$, which depends on $\phi$. Solving $\zeta_{1}$ from the characteristic equation (5) and taking the first derivative with respect to the degree of exchange rate accommodation $(\phi)$ yields:

Install Equation Editor and doubleclick here to view equation.

\footnotetext{
${ }^{5}$ Note that equation (4) deviates from AS due to some computational errors on their side.
} 
Install Equation Editor and double-

click here to view equation.

with

Equations (3)-(6) significantly differ from AS due to a mistake in their derivation of the relative wage equation. The sign of the first derivative now becomes ambiguous instead of strictly positive as claimed by AS. ${ }^{6}$ Ultimately, the sign in (6) depends on $\chi$. Since the expression $\left(1+b\left(b^{2}-4 c\right)^{-1 / 2}\right)$ can be shown to be negative, the first derivative in (6) is positive if $\chi$ exceeds some small negative number. For $\chi$ large and negative, the sign becomes negative.

AS explain their results in quite general terms only, referring to the interaction of the wage- and price-setting behaviour. Contrary to Dornbusch (1982), they fail to precisely discuss the various transmission mechanisms. In our discussion, we add to the intuition of our result by focusing on the three components of $\chi$, which each correspond to a distinct transmission channel: $2 \lambda(1-\delta), 2 \lambda \varepsilon \beta$, and $\varepsilon \alpha$ respectively. We try to explain the link from higher accommodation $(\phi)$ to higher persistence $\left(\zeta_{1}\right)$ through each channel individually.

The first channel $2 \lambda(1-\delta)$ is related to the indexation of wages to expected prices. Since both domestic and foreign wage-setters consume a mix of domestic and foreign goods, a positive domestic price shock puts upward pressure on wages in each of the two countries (with wage responsiveness $\delta$ and (1- $\delta$ ) for the home and foreign country respectively). However, an increase in exchange rate accommodation reduces this wage pressure for the foreign country (higher prices

\footnotetext{
${ }^{6}$ AS claim that Dornbusch (1982) also finds a strictly positive link between exchange rate accommodation and inflation persistence. This is incorrect. Dornbusch distinguishes two offsetting channels: one works through the demand side and increases persistence, the other through the supply (cost) side, which decreases persistence. The net effect is uncertain, similar to our conclusion.
} 
on domestic goods are compensated partly by a depreciating domestic currency), while it increases wage pressure at home: not only domestic goods become more expensive, but imported foreign goods as well. As a result, the relative wage differential increases and becomes more persistent due to the interaction of forward-looking price- and wage-setters.

The second effect $2 \lambda \varepsilon \beta$ comes from the real exchange rate effect on relative output. A domestic real appreciation through a positive domestic price shock, leads to a decline in relative output $(\beta)$ and thus higher relative unemployment and lower relative wages $(\varepsilon)$, which in turns leads to lower relative prices, that moderate the initial price shock. Increasing exchange rate accommodation lowers the real exchange rate effect on output, unemployment and wages. Thus, less compensation of the initial price shock occurs and persistence increases.

The third channel $\varepsilon \alpha$ counteracts the first two effects. A positive price shock implies higher expected inflation through the interaction of wage- and price-setters. Lower relative real interest rates result, which stimulate relative output $(\alpha)$ and via lower unemployment increase relative wages $(\varepsilon)$ and prices. However, higher exchange rate accommodation increases expected depreciation. Because of intereste rate parity, relative nominal interest rates then increase, so that the real interest rate effect is decreased and persistence is lowered.

In summary, higher exchange rate accommodation unambiguously leads to higher relative inflation persistence only when the first two transmission channels dominate the last one. In practice, this may well be the case. ${ }^{7}$ Also, additional coefficient restrictions may be imposed to obtain a positive first derivative in (6). For example, sufficient conditions are the absence of a real interest rate effect on output $(\alpha=0)$, or the absence of an unemployment effect on real wagesetting $(\varepsilon=0)$. When these assumptions seem to far-fetched, weaker but intuitively appealing

\footnotetext{
${ }^{7}$ The empirical results in AS provide supportive evidence of a positive link between real exchange rate accommodation and relative inflation persistence.
} 
assumptions may do the job as well. The discount rate $\lambda$ probably is close to one. Then, if output is about half as responsive to real exchange rate shocks as it is to real interest rate shocks, the second and third transmission channels approxiately cancel, so that the wage-indexation effect dominates. Arbitrarily low values of $\varepsilon$ (or $\alpha$ ) will suffice as well, given the positive wageindexation effect.

\section{Expected real exchange rate mean reversion}

In this section we propose a modification of the original model to find a strictly positive link between exchange rate accommodation and relative inflation persistence, instead of imposing additional coefficient restrictions. One of the peculiarities of the original model are the implications for real exchange rate developments. Under positive relative inflation persistence and zero exchange rate accommodation, domestic and foreign price levels can diverge without bounds. Consequently, real exchange rates are allowed to display persistent trends as well. This is at odds with both theoretical real exchange rate models and empirical work on real exchange rates. The latter category generally points to slow mean reversion of real exchange rates. Here, we modify the AS model in an admittedly ad hoc way to reflect the stylized facts on real exchange rate behavior. More precisely, we impose expected real exchange rate mean reversion by adding the following equation to the original model:

Install Equation Editor and doubleclick here to view equation. 
where the real exchange rate $e r_{\mathrm{t}}$ is defined as click here to view equation. . Without loss of

Install Equation Editor and double-

generality, the equilibrium real exchange rate click here to view equation. is set to zero. ${ }^{8}$ Using the same procedure as before, the following second-order equation for relative prices results:

Install Equation Editor and doubleclick here to view equation.

Install Equation Editor and doubleclick here to view equation.

Install Equation Editor and double-

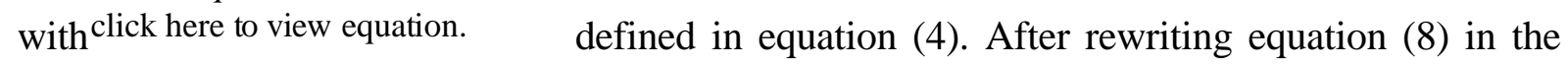
general second-order form of (5), expression (6') for the first derivative may be obtained:

Install Equation Editor and double-

click here to view equation.

The same three transmission channels can be distinguished as in (6). However, the first derivative is unambiguously positive again. The crucial difference is the positive sign on the real interest rate channel $\varepsilon \alpha(1+\eta)$. This effect may be explained as follows.

For a given degree of exchange rate accommodation, a domestic price shock raises the relative price level. The real exchange rate then appreciates away from its equilibrium level, giving rise to expected real home depreciation. In turn this requires higher relative real interest rates. Via the goods market, lower relative output and higher relative unemployment put downward pressure on relative wages. In the end a moderating effect on relative prices results, through the interaction of wage- and price-setters. Suppose now that the degree of exchange rate accommodation

\footnotetext{
${ }^{8}$ The inclusion of equation (7) only affects the relative model. Since the average model actually comprises the whole two-country world, it becomes a closed economy model in which all exchange rate terms disappear anyway.
} 
increases. The real exchange rate then appreciates less in real terms, because the nominal exchange rate is allowed to do part of the job, relative real interest rates rise less and the impact of the transmission mechanism described above decreases. That is, the moderating effect diminishes and relative inflation persistence increases.

\section{REFERENCES}

Alogoskoufis, George S., "Monetary Accommodation, Exchange Rate Regimes and Inflation Persistence", The Economic Journal, May 1992, 102, 461-480.

Alogoskoufis, George S. and Ron Smith, "The Phillips Curve, the Persistence of Inflation, and the Lucas Critique: Evidence from Exchange-rate Regimes", The American Economic Review, December 1991, 81, 1254-1275.

Dornbusch, Rudiger, "PPP Exchange-Rate Rules and Macroeconomic Stability", Journal of Political Economy, February 1982, 90, 158-165.

Lammertsma, Alex, "Inflation-Output Trade-Offs and the Implications for Monetary Policy", 1997, University Press Maastricht, chapters 5 and 6. 